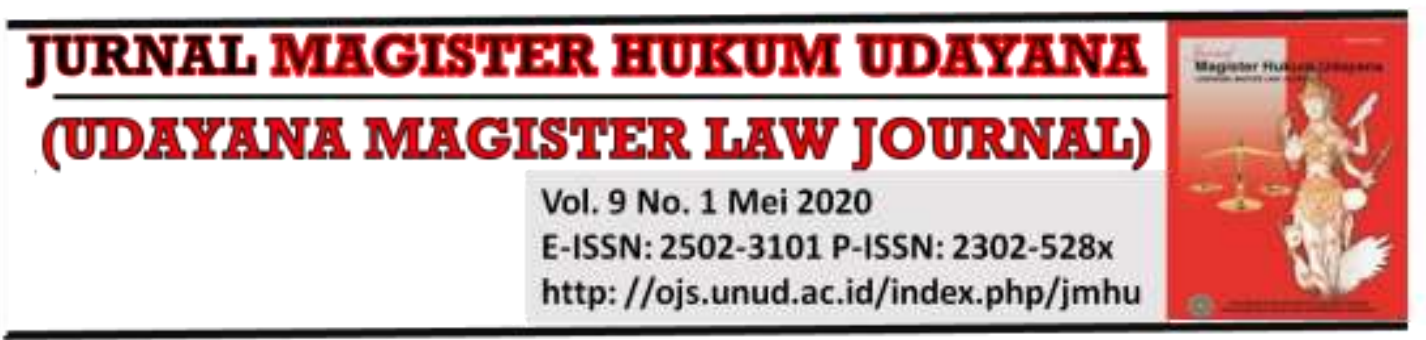

\title{
Implementasi dari Corporate Negligence dan Relevansi Quasi Economic Credentialing dalam Praktik di Rumah Sakit Swasta
}

\author{
Theodorus HW Lumunon', Liju Zet Viany², Butje Tampi \\ Caecelia J. J. Waha ${ }^{4}$
}
1Fakultas Hukum Universitas Sam Ratulangi, E-Mail: theodoruslumunon@unsrat.ac.id
2Fakultas Hukum Universitas Sam Ratulangi, E-Mail: lijuzet@unsrat.ac.id
3Fakultas Hukum Universitas Sam Ratulangi, E-mail: butjetampi@unsrat.ac.id
4Fakultas Hukum Universitas Sam Ratulangi, E-mail: annewaha97@gmail.com

\begin{tabular}{l}
\hline Info Artikel \\
\hline Masuk: 11 September 2019 \\
Diterima: 9 Maret 2020 \\
Terbit: 31 Mei 2020 \\
Keywords: \\
corporate negligence; quaci \\
economic credentialing; medical \\
privileges and scheme target.
\end{tabular}

Kata kunci:

kelalaian korporasi; kuasi

ekonomi kredensial; kewenangan medik dan skema target.

Corresponding Author:

Theodorus HW Lumunon,

Email:

theodoruslumunon@unsrat.ac.id

\begin{abstract}
The prevailing law of the hospital liability for every damage occured by the health professionals in hospital falls into very broad sense and leaving many critical questions about how this definition to be applied. The question addressed whether the hospital may defend it's position by proving that the negligence by the health professionals was caused beyond the hospital guidelines such as the theory of professional liability scheme?. Purpose: to explain the hospital liability based on the corporate negligence theory, and to identify the implementation of economic credential in private hospitals. Method: using the normative juridical method, through legislation approach, concepts and legal comparison and also supported by the data field such focus group discussion. Results: Health professionals can be liabiled if she/he has found deviate by the professional medical standards. The hospital was liabiled for every damage occured by the health professional based on the "vicarious liability" scheme. The medical negligence according to the perception of health law is different from the general negligence in the legal perception. The economic credentialing actually has exist with some modification such as "scheme target", or what we called the "quasi economic credentialing".
\end{abstract}

\begin{tabular}{l} 
Abstrak \\
\hline Rumah Sakit bertanggung gugat terhadap kerugian yang \\
diakibatkan oleh tenaga kesehatan yang bekerja di rumah sakit. \\
Konsep ini menimbulkan pertanyaan mengenai beban \\
pembuktian apakah pihak rumah sakit dapat mengelak dengan \\
argumen bahwa kelalaian tenaga kesehatan itu sudah bertindak \\
di luar skema tanggung jawab rumah sakit sebagaimana \\
umumnya berlaku pada teori pertanggungjawaban. Artikel ini \\
bertujuan untuk menjelaskan tanggung gugat rumah sakit \\
berdasarkan teori corporate negligence, dan mengidentifikasi \\
bagaimana pelaksanaan economic credentialing di rumah sakit \\
swasta. Penelitian ini menggunakan metode yuridis normatif, \\
dengan pendekatan, perundang-undangan, konsep dan \\
perbandingan hukum, dan data lapangan sebagai penunjang.
\end{tabular}


DOI:

10.24843/JMHU.2020.v09.i01.p 13

\section{Pendahuluan}

Pertumbuhan rumah sakit swasta, dengan bentuk badan usaha perseroan terbatas dan berbentuk yayasan di Wilayah Sulawesi Utara telah mencapai jumlah lebih dari sepuluh. Umumnya berupaya memberi kesan dengan jangkauan pelayanan ramah, ditunjang dengan penggunaan teknologi kedokteran canggih dan aman bagi pasien, kemudian pelayanan kesehatan berstandar nasional, dan malah dicitrakan bertaraf internasional dengan memiliki tenaga kesehatan spesialis yang profesional.

Di kota Manado terdapat 3 rumah sakit swasta dengan klasifikasi B menawarkan pelayanan kamar dan perawatan kelas VIP. Selain itu ada beberapa rumah sakit skala kecil dengan klasifikasi Rumah Sakit Ibu dan Anak (RSIA), dan sebagian besar bertujuan profit.

Rumah sakit sebagai wadah bagi tenaga kesehatan dalam menjalankan profesinya, terjadi perkembangan, mulai dari tempat ibadah yang oleh Aesculapius di Epidaurus sampai abad 20 tidak menyimpang dari tujuan awal yaitu memberikan perawatan, pelayanan, dan tempat bagi mereka yang sakit, adalah merupakan bentuk partisipasi dalam masyarakat sebagai sistem sosial ${ }^{1}$

Rumah Sakit Swasta berkewajiban mengutamakan pelayanan sosial, dengan memberikan fasilitas pelayanan bagi pasien yang tidak mampu, namun tidak memiliki sifat imunitas dari segi pertanggungjawaban hukum. Berbeda dengan status imunitas pada rumah sakit yang bergerak di bidang sosial di Amerika pada tahun tujuh puluhan. Pada saat itu di Amerika, berlaku prinsip imunitas, yang memberikan kekebalan bagi rumah sakit yang memberikan pelayanan kemanusiaan dari tuntutan malpraktik medis ${ }^{2}$.

Institusi rumah sakit telah berkembang dengan pesat, tidak hanya rumah sakit pemerintah yang berupaya meningkatkan mutu pelayanan, terlebih pada rumah rumah sakit swasta. Perawatan kesehatan di rumah sakit swasta dengan bentuk badan usaha perseroan terbatas, telah dianggap sebagai industri kesehatan yang masuk dalam jajaran bisnis. Persaingan antar rumah sakit semakin tinggi baik dari segi

${ }^{1}$ Koeswadji HH. (2002). Hukum Untuk Perumahsakitan, PT Citra Aditya Bakti Bandung. h. 43.

2 Crowter Law Firm. Charitable Immunity for Nonprofit Hospitals. Available from https://www.clf-law.com/Medical-Malpractice-Newsroom/Charitable-Immunity-for-

Nonprofit-Hospitals.shtml, diakses 5 Juli 2019. ospital Appraisal Process. Legal Med, Vol 12 J, Issues 4. doi.org/10.1080/01947649109510864 
fasilitas, sumber daya manusia, tingkat pelayanan maupun teknologi kedokteran yang ditawarkan. Secara tidak langsung membawa perubahan besar pada peningkatan manajemen rumah sakit, tenaga medis sub spesialis yang ditawarkan, dan tenaga spesialis yang harus dimiliki, termasuk faktor penting besarnya modal yang diinvestasikan untuk menjalankan pelayanan rumah sakit. Rumah sakit modern mengharuskan memiliki manajemen yang mampu menjaga keberlanjutan, termasuk juga secara terus menerus meningkatkan investasi untuk melengkapi fasilitas kedokteran (alat kesehatan). Demi memenuhi tuntutan ini, maka rumah sakit modern harus mampu menyediakan tenaga medis yang memiliki kapabilitas, teknologi kedokteran standar terkini, serta manajemen keuangan yang solid.

Penelitian ini berusaha menjawab dua hal pokok, yaitu pertama, dalam hal terjadi kelalaian yang dilakukan staf medis pada saat praktik menjalankan kewenangan klinis di rumah sakit, apakah rumah sakit dapat di mintakan tanggung gugat. Proses kredensial terhadap staf medis yang melakukan praktik di rumah sakit merupakan sebuah proses evaluasi agar terjaga profesionalismenya. Kegiatan ini dilakukan oleh komite medik.

Permasalahan berikutnya adalah bagaimana wujud dari pelaksanaan economic credentialing di rumah sakit swasta, dengan sifat perusahaan yang berorientasi laba. Proses kredensial mengikutsertakan pertimbangan ekonomi, berada pada kewenangan administrator rumah sakit ${ }^{3}$. Istilah economic credentialing menjadi acuan pada penggunaan kriteria ekonomi dalam menentukan performa staf medis. ${ }^{4}$ American Medical Association (AMA) mendefinisikan economic credentialing sebagai penggunaan kriteria ekonomi yang tidak terkait dengan kualitas perawatan atau kompetensi profesional dalam menentukan kualifikasi staf medis untuk memperoleh clinical privilege. 5 Gagasan lain yang menolak terhadap economic credentialing, berpandangan bahwa harus diutamakan pertimbangan kualitas profesional staf medis. ${ }^{6}$ Menurut Marc S. Raspanti dan David M Laigaie, economic credentialing adalah gabungan pertimbangan kriteria ekonomi dengan kualitas pelayanan medis. ${ }^{7}$ Kegiatan ini merupakan proses evaluasi terhadap staf medis atas pertimbangan kriteria ekonomi dan kelayakan pelayanan medis. Secara singkat economic credentialing melakukan analisa ekonomi dari praktik klinis staf medis di rumah sakit. ${ }^{8}$

Dalam risalah materi novum kasus dr. Ayu Sasiary, dkk, dikemukakan bahwa kelalaian medis harus dibedakan dengan kelalaian umum dalam persepsi hukum ${ }^{9}$, kelalaian medis batas dan ukurannya ditentukan oleh kelompok sebaya yang

${ }_{3}^{3}$ Blum, J. D. (1991). Economic Credentialing: The New Twist: In The H, p. 427

${ }_{4}^{4}$ Black, S. \& Evans, R. (2012). Economic Credentialing of Physicians by Insurance companies and Headache Medicine, Headache, 52 (6), 1037 - 1040.

5 Ibid

${ }^{6}$ DiFranco, S. (2000). Denying medical staff privileges based on economic credentials. JL $\mathcal{E}$ Health, 15, 247.

7 Cohen,B. (2004). An Examination of the Rigth of Hospitals to Engage in Economic Credentialing. Temp. L.Rev., 77, 705.

8 Riley, D. W. (1996). Economic credentialing of physicians: new criteria and evaluation of physicians. Spine, 21(1), 141-146.

9 Putusan Mahkamah Agung Nomor 79/PK/10/2013 tahun 2013. Dr Ayu Sasiary Prawani dkk. 
dinamakan mitra bestari (peer group), yang kedudukannya berada pada organisasi komite medik. Dalam Peraturan Menteri Kesehatan No 755 /Menkes / per/IV/2011 tentang Penyelenggaraan Komite Medik di Rumah Sakit, Mitra Bestari (peer group) adalah sekumpulan staf medis, yang memiliki reputasi dan kompetensi untuk melaksanakan dan menegakkan Medical Bylaws di rumah sakit, termasuk mengevaluasi semua tindakan intervensi medik yang dilakukan oleh seorang staf medis di dalam maupun di luar kamar operasi.

Kelalaian medik dapat berakibatkan fatal. Di sinilah tanggung jawab profesi dengan akibatnya yang belum tentu dapat dipertanggungjawabkan secara hukum, ini yang biasanya disebut resiko medis, sementara kelalaian hukum adalah asumsi dalam kategori hukum pidana. Pasal 46 Undang-Undang Nomor 44 tahun 2009 tentang Rumah Sakit, menentukan bahwa rumah sakit bertanggung jawab secara hukum terhadap semua kerugian yang ditimbulkan atas kelalaian yang dilakukan oleh tenaga kesehatan di rumah sakit. Ketentuan kelalaian dalam konteks undang-undang rumah sakit tersebut adalah pengertian dalam konteks kelalaian perbuatan melawan hukum menurut hukum perdata.

Berkaitan dengan tanggung jawab profesi sangat signifikan memperhatikan perkembangan internal rumah sakit dalam kaitannya dengan rekruitmen staf medis di rumah sakit. Setelah melalui tahap evaluasi melalui proses kredensial oleh komite medik, staf medis memiliki hak dalam menjalankan praktik di rumah sakit. Apakah staf medis yang mempunyai hak tersebut berdasarkan tanggung jawab profesi dapat melepaskan tanggung gugat rumah sakit.

Apakah telah berlaku pelaksanaan "economic credentialing" dalam rupa yang sederhana sekalipun, terutama di rumah sakit swasta yang menawarkan berbagai perawatan dan tindakan medik yang didukung teknologi kedokteran canggih. Risiko hukum apa yang terjadi sebagai akibat pelaksanaan kebijakan economic credentialing pada pelayanan rumah sakit swasta yang didirikan untuk tujuan profit. Penelitian ini melibatkan isu-isu di atas yang mempunyai korelasi satu dengan yang lain.

\section{Metode Penelitian}

Jenis penelitian ini adalah yuridis normatif ditunjang data lapangan sebagai penunjang. Pendekatan yang digunakan, pendekatan perundang-undangan yaitu melakukan penilaian terhadap Pasal 46 UU Rumah Sakit dan peraturan lain yang relevan. Pendekatan konseptual untuk memberi kejelasan terhadap konsep yang digunakan, seperti doktrin corporate negligence. Pendekatan perbandingan hukum dilakukan dengan sistem hukum common law serta pendekatan kasus atas putusan pengadilan di Amerika dan di Indonesia, untuk menjelaskan pemecahan masalah. Analisa bahan kepustakaan dan peraturan perundang-undangan yang mengatur tentang corporate negligence dan economic credentialing dijelaskan dengan langkahlangkah normatif. Analisis dilakukan secara deskriptif analitis. Data lapangan, hasil focus group discussion, dianalisis secara kualitatif melalui proses snow-balling. 


\section{Hasil dan Pembahasan}

\subsection{Perkembangan Negligence (Kelalaian): Berdasarkan Teori dan Kasus}

Tanggung jawab berdasarkan profesi, terutama yang berlaku di lingkungan kedokteran adalah merupakan gabungan dari berbagai aturan yang berlaku secara bersamaan, meliputi secara etik, moral maupun prosedural. Dokter (staf medis) dan pilot merupakan dua profesi yang berbeda tetapi keduanya mempunyai persyaratan mutlak, yaitu tidak diperkenankan melakukan kelalaian dan kesalahan.

Mengapa etika, moral, dan prosedural menjadi sangat penting. Di rumah sakit terdapat berbagai ketentuan seperti; (i) standar pelayanan, (ii) standar perawatan, (iii) standar profesi, (iv) standar etik, (v) protocol: clinical pathway, (vi) medical bylaws, dan (vii) hospital bylaws, belum terhitung adanya aturan administrasi yang harus dilaksanakan bersamaan di rumah sakit, maupun ketentuan-ketentuan yang merupakan hasil kesepakatan profesi tentang prosedur tindakan tertentu sebagai respons adanya penemuan penyakit baru ataupun teknologi baru. Kesemuanya merupakan konsekuensi dari adanya situasi "uncertainty in medical treatment."

Staf medis harus memenuhi berbagai kewajiban sebagaimana di atur dalam berbagai peraturan antara lain: Undang-Undang Nomor 36 Tahun 2009 tentang Kesehatan, Undang-Undang Nomor 29 Tahun 2004 tentang Praktik Kedokteran, Undang-Undang Nomor 36 Tahun 2014 tentang Tenaga Kesehatan, Undang-Undang Nomor 40 Tahun 2004 tentang Penyelenggaraan Jaminan Kesehatan dan Sosial Indonesia. Ketentuan Peraturan Menteri Kesehatan Nomor 290/MENKES/III Tahun 2008 tentang Persetujuan Tindakan Medik. Semua peraturan tersebut, harus mematuhi Sumpah Dokter Indonesia, Code of Conduct World Medical Profession, serta Medical Bylaws dan Hospital Bylaws di rumah sakit.

Ketentuan dimaksud untuk menegakkan profesionalisme staf medis, menjamin kualitas pelayanan kesehatan termasuk melindungi keselamatan pasien. Apabila telah terjadi penyimpangan terhadap ketentuan tersebut yang berakibat lalai, maka akan dievaluasi melalui wadah audit medis di rumah sakit, yaitu komite medis.

Di negara common law malpraktik medis masuk dalam konteks kelalaian wilayah hukum privat karena adanya profesional relationship ${ }^{10}$. Kelalaian umum dalam persepsi hukum Indonesia termasuk dalam konsep hukum pidana yang dalam persepsi kedokteran dirasakan sangat mengganggu. Khalayak hampir tidak menyadari bahwa tindakan seorang dokter selalu dievaluasi dan re evaluasi oleh mitra bestari (peer group), untuk menentukan apakah terjadi penyimpangan terhadap berbagai standar: seperti standar profesi (code of conduct), standar perawatan (standard of care), atau clinical pathway yang sudah disepakati bersama untuk penanganan penyakit tertentu. Bahasa kelalaian dalam bidang kedokteran mempunyai konotasi dan ukuran berbeda, karena telah menjadi kebiasaan dimana seorang pasien ditangani oleh beberapa dokter, apalagi jika terdapat penanganan invasif. Jarang sekali seorang dokter menangani pasien seorang diri, sehingga satu dengan yang lain saling mengingatkan. Kata kelalaian dalam konteks medis merupakan sebuah malapetaka.

10 Nasser Mohammad. Pidana Medik Bukan Pidana Umum, Pertemuan Imiah Tahunan (PIT) Masyarakat Hukum Kesehatan Indonesia (MHKI), Jakarta, September 2017. h. 3. 
Kelalaian dalam persepsi hukum selalu melibatkan faktor korban, mati atau luka parah (death or harmful). Sementara pelaku subyek adalah mereka yang memenuhi kriteria umum seperti umur, jenis kelamin dan oleh perbuatannya seseorang mati atau luka parah. Mengapa disebut harus memenuhi kriteria umum? Artinya seorang pengemudi kendaraan hanya diizinkan jika telah memiliki Surat Izin Mengemudi (SIM), dan tidak mempersoalkan apakah yang bersangkutan tamatan SMA, PT, Dosen, juga dokter, perempuan atau laki-laki. Sepanjang telah memenuhi persyaratan untuk mengemudi.

Seseorang selaku dokter, kemudian berpraktek dokter Umum, berlanjut Spesialis, yang bersangkutan tentunya harus menyelesaikan sekolah kedokteran (S.Ked), diharuskan mengikuti program internship. Selanjutnya mengikuti ujian profesi. Artinya kepada mereka diberlakukan persyaratan-persyaratan khusus dimana tidak setiap dokter dapat mengikutinya, atau dapat memiliki izin praktik, apalagi tindakan khusus seperti bedah, operasi Caesar pertolongan persalinan. Kepada mereka berlaku ketentuan khusus (lex specialis).

Bagaimana kategori "kelalaian umum" dalam persepsi hukum, pada kategori ini dapat diberlakukan secara serta merta atau apakah dapat disamakan dengan "kelalaian medis" atau diterapkan pada seorang dokter"? ${ }^{11}$ Selain oleh karena kelalaian hukum lebih melihat pada akibat buruk12, sementara ketidakpastian dalam dunia kedokteran sangat lebar. Ketidakpastian dalam pelayanan kesehatan merupakan faktor $X$ dengan variable yang tidak terkontrol. Gejala bisa sama, namun faktor kekhususan dalam tubuh seseorang, membuat setiap diagnose dan prognosis dari setiap pasien berbeda.

Di bidang medik, lebih ditekankan pada aspek protokol (prosedur tindakan dan proses), sedangkan hasil yang baik merupakan kehormatan bagi seorang dokter, dan ketidak berhasil merupakan malapetaka. Perbuatan kelalaian mempunyai konotasi negatif dalam profesi kedokteran. Kelalaian dalam pengertian medis merupakan perbuatan tercela dan tidak mudah terjadi dengan adanya berbagai prasyarat sebelum sebuah tindakan dilakukan.

Upaya telah dilakukan untuk membuka tabir masalah di atas meskipun belum terjadi kesepakatan di bidang hukum kedokteran, melalui contoh kasus dr. Ayu Sasiary Prawani, dkk yang sebelumnya melalui keputusan MA No. 365K./PID/2012 13 dianggap lalai dalam menangani tindakan medis persalinan. Ketiga dokter mengajukan Peninjauan Kembali (PK) upaya ini dilakukan karena terdapat kekeliruan hakim dalam menerapkan hukum, bersamaan dengan itu dr. Ayu Sasiary, dkk bermohon untuk penundaan eksekusi pidana disertai beberapa alasan, antaranya surat dari IDI Manado Nomor 19-U/IDI/MDO/VII/2013, Tanggal 31 Juli 2013 yang

11 Tambun, J. G. (2016). Hukum Kesehatan Kedokteran dan Rumah Sakit. Manado: Pacific Institute for Sustainable Development Indonesia, P 174 ISBN 978-602-19035-5-1.

12 Tambun, J. G. (2015). Persoalan Private Order Versus Public Order Dalam Hubungan Dokter Pasien, World Medical Congress, Denpasar Nusa Dua, Agustus 2015. h. 3-5.

13 Putusan Kasasi Mahkamah Agung yang mengabulkan permohonan Kasasi Jaksa Penuntut Umum dan memutuskan bahwa ketiga dokter yaitu masing-masing dokter Ayu Sasiary, Henry Siagian dan Simanjuntak terbukti secara sah dan meyakinkan lalai dalam menangani korban saat pelaksanaan operasi cito secsio sesaria dan dijatuhi hukuman penjara 11 bulan. 
menyatakan secara profesional, ketiga dokter tersebut tidak melanggar standar perawatan dan etika.

Putusan Peninjauan Kembali, Mahkamah Agung No. 79/PK/10/2013, mengabulkan permohonan peninjauan kembali. Membatalkan putusan MA No. 365 K./PID/2012 . Menyatakan ketiga dokter tidak menyimpang standar profesi kedokteran, standar prosedur Obtetric-genecology. Kesaksian ahli yang menyatakan kelalaian kedokteran, memiliki perbedaan dengan kelalaian hukum, diterima majelis hakim. Keputusan ini sebagai yurisprudensi dalam menangani kasus malpraktik medis.

Perkembangan teori corporate negligence sehingga memunculkan institutional liability dalam lingkungan hukum common law sudah demikian maju, terutama ketika putusan pengadilan dengan memasukan pertimbangan dan keterlibatan pihak ketiga seperti perusahan asuransi atau adanya asuransi milik pemerintah. Pada Wickline v. California pengadilan memutuskan holding that the patient's treating physician was solely responsible for the harm that she had suffered. ${ }^{14}$

Pertanggungjawaban langsung pada rumah sakit dapat pula didasarkan pada kenyataan bahwa rumah sakit mengawasi orang yang bekerja kepadanya berdasarkan doctrine vicarious liability dan corporate liability sebagai akibat adanya corporate negligence. 15

Syarat-syarat diterapkan tanggung gugat pada rumah sakit ada di bawah doctrine corporate negligence for negligent failure is: (a) maintain safe and adequate facilities and equipment for patients; (b) select and retain only competent physicians; (c) oversee all persons who practice medicine within their walls as to patient care; and (d) formulate, adopt, and enforce adequate rules and policies to ensure quality care for patients. ${ }^{16}$

\subsection{Ulasan Praktis : Rumah Sakit dan Quasi Economic Credensialingl}

Perkembangan rumah sakit dan investasi rumah sakit serta teknologi kedokteran, terutama pada rumah sakit yang berorientasi profit, dengan entitas hukum perusahaan, penuh dengan kompetisi. Menawarkan berbagai jenis perawatan yang ampuh dan dengan teknologi yang populer, sehingga membuat pelayanan kesehatan menjadi sebuah industri di samping, adanya keterlibatan multi pihak seperti farmasi, produk nutrisi dan makanan maupun asuransi (BPJS), atau asuransi swasta lainnya.

Semakin canggih peralatan kedokteran yang disediakan rumah sakit, semakin besar pula investasi yang harus ditanamkan. Beberapa rumah sakit menikmati kelebihan hasil usahanya, dari internal jaringan grupnya. Beberapa rumah sakit lainnya harus bertumpu pada pendapatan yang diperoleh dari pembayaran pasien maupun perusahan asuransi kesehatan.

Rumah sakit swasta di Indonesia, secara informal mulai menerapkan "kebijakan" target pencapaian tertentu, dalam pengertian finansial pada dokter-dokter spesialis

\footnotetext{
14 Emmanuel O. Iheukwumere. (2000). Application of the Corporate Negligence Doctrine to Managed Care Organizations: Sound Public Policy or Judicial Overkill? Corporate, Journal of Contemporary Health Law \& Policy. Vol. 17, Issues 2, P.585.

15 Ibid.

16 Thompson v. Nason Hospital, 591 A.2d 703, Pensylvania Supreme Court. 20 May 1991.
} 
yang telah memiliki hak untuk melakukan praktik di rumah sakit. Staf medis yang telah melewati proses kredensial memiliki kewenangan klinis (clinical privilige) ${ }^{17}$, untuk menjalankan praktik di rumah sakit (medical staff privilige), yaitu kewenangan mandiri dan otonom dalam menjalankan profesi di rumah sakit ${ }^{18}$.

Perkembangan saat ini di Amerika, menyangkut kebijakan yang dimaksud lebih terintegrasi pada proses rekruitmen tenaga dokter spesialis pada credentialing process ${ }^{19}$. Secara sederhana proses 'credentialing' is the process of evaluating the qualifications and practice history of a medical provider. Physicians and healthcare providers have been undergoing a credentialing process. ${ }^{20}$

Proses kredensial ini berlaku setelah semua syarat terpenuhi, seorang dokter harus pula menyertakan dokumen yang menunjukkan rekam jejak ekonomi yang sudah berhasil dicapai oleh dokter tersebut pada rumah sakit, dimana dokter tersebut sebelumnya bekerja. Rekam jejak ini penting bagi pihak administrator rumah sakit sebagai bahan pertimbangan, Prosedur ini disebut dengan credentialing on medical staff privileges 21 . Sebuah proses kredensialing disertakan pertimbangan-pertimbangan ekonomi demi kepentingan rumah sakit. Hal ini merupakan kewenangan pihak administrator selaku pemegang kebijakan rumah sakit.

Dalam perkembangan proses kredensial dengan pertimbangan ekonomi ini menyentuh persoalan anti-trust dan conspiracy ${ }^{22}$. Terutama ketika proses kredensial itu telah melewati batas etik dan moral pelayanan kesehatan, dimana faktor pertimbangan ekonomi menjadi lebih utama dari pada aspek profesionalisme.

Di Indonesia dengan maraknya pertumbuhan rumah sakit sebagai industri jasa pelayanan kesehatan, di tingkat nasional maupun daerah, mulai berekspansi mengembangkan citra bertaraf internasional, sehingga kompetisi di antara rumah sakit semakin ketat. Apakah model economic credentialing telah teradopsi penuh pada rumah sakit swasta di Indonesia? Inti dari pertanyaan tadi adalah apakah pertimbangan ekonomi menjadi penilaian penting dalam menentukan seorang dokter diterima dan bekerja sebagai anggota medical staff privileges? Adakah model atau bentuk lain dari economic credentialing di Indonesia?

\subsubsection{Model Quasi Economic Credentialing: Sistem Target}

Focus group discussion dipilih sebagai instrumen pengumpulan data kualitatif yang menyertakan 15 informan utama dengan latar belakang staf medis yang telah memiliki kewenangan klinis di rumah sakit swasta. Dilaksanakan dengan mengajukan 2

17 Pasal 1 (7). PERMENKES RI No 755/MENKES/PER/IV/2011 tentang Penyelenggaraan Komite Medik Di Rumah Sakit.

18 American Medical Association. https://www.ama-assn.org/delivering-care/staff-privileges, diakses 4 Juli 2019.

19 Tambun, J. G. Hukum Kesehatan Kedokteran dan Rumah Sakit. Op.cit. h. 147-151.

20 Brad Ranks. (2015). What Credentialing and Why is it Important EJLT https:// blog.memd.me/what-is-credentialing-and-why-is-it-important/, diakses 4 Juli 2019.

${ }_{21}$ Blum, J. D. (1991). Hospital-Medical Staff Relations in the Face of Shifting Institutional Business Strategies: A Legal Analysis, U Puget Sound L Rev, Vol 14, P 561, 583

22 Enders, R. J. (1985). Federal Antitrust Issues Involved in the Denial of Medical Staff Privileges. Loy. U. Chi. LJ, 17, 331. 
pertanyaan pokok. Pertama berkaitan tentang implementasi Pasal 46 Undang-Undang Nomor 44 Tahun 2009 tentang Rumah Sakit. Hal ini menyangkut persepsi informan tentang pengejawantahan corporate negligence. Mengenai kelalaian yang dilakukan staf medis dan menjadi tanggung-jawab rumah sakit, mayoritas informan tidak memberi jawaban setuju atau tidak namun memberikan komentar tentang kelalaian dalam bidang medik merupakan ranah profesi medis bukan hukum.

Pertanyaan kedua terkait pendapat informan mengenai wujud economic credentialing dalam bentuk bagaimana, sejumlah kecil saja yang mengetahui bahwa dokter-dokter spesialis tertentu, terutama bidang spesialisasi dengan tindakan kedokteran yang menggunakan alat kesehatan berbasis teknologi canggih. Dokter spesialis tersebut diwajibkan mencapai target finansial tertentu dalam kurun waktu tiga bulan. Ternyata ada rumah sakit swasta Kota Manado dengan entitas hukum sebagai sebuah korporasi telah menerapkan model target demikian pada dokter spesialis.

\subsection{Implikasi Target Model}

Faktor ekonomi dalam tatanan institusional bagaimanapun tidak bisa diabaikan. Rumah sakit yang dibentuk berdasarkan badan usaha perseroan terbatas bertujuan mencari laba. Konteks pelayanan kesehatan di beberapa rumah sakit swasta, berusaha mengesankan bersifat sosial, yaitu menjaga keseimbangan pembiayaan dengan melakukan subsidi silang secara internal. Hal ini tidak dapat dilakukan dalam jangka panjang. Pihak administrator rumah sakit yang dianggap bertanggung jawab selalu mempunyai kepentingan demi sebuah keuntungan.

Kualitas rumah sakit bergantung pada staf medis terampil, sarana kesehatan yang memadai dan teknologi medis canggih. Keadaan ini membutuhkan dana guna memenuhi biaya operasional, membayar gaji dan jasa profesi dokter umum dan dokter spesialis serta pembelian peralatan kesehatan. Telah menjadi kebiasaan belanja barang untuk kebutuhan rumah sakit, dimana hampir semua peralatan kesehatan yang tersedia dalam posisi hutang dengan kewajiban pembayaran per bulan atau pertiga bulanan.

Bidang-bidang spesialisasi yang sarat dengan teknologi kedokteran, pada umumnya mempunyai kewajiban lebih besar yang dibebankan pada dokter-dokter spesialis di bidang itu. "Target model" masih tergolong rasional, meskipun berhadapan dengan pertanyaan-pertanyaan moral. Rumah sakit tertentu tidak menyatakan dengan jelas atau tersurat mengenai target kebijakan, namun menjadi kebijakan "di belakang layar" dimana setiap administrator rumah sakit maupun dokter spesialis menganggap sangat serius jika target tidak dipenuhi.

Saat ini target model belum menunjukkan adanya degradasi terhadap etika dan moral pelayanan kesehatan. Namun dalam beberapa kasus, sudah nyata berimplikasi terhadap perujukan pasien dan keinginan untuk melakukan tindakan medis pada pasien-pasien dengan gejala jantung, leukemia ataupun untuk tindakan pembedahan. Dewasa ini telah menjadi isu yang sangat sentral, tidak saja terkait pada target model tetapi yang berhubungan dengan pasien-pasien BPJS yang dirujuk oleh fasilitas kesehatan C ke fasilitas kesehatan B. Kehadiran program Asuransi Nasional maupun adanya private health insurance corporate yang mengikat perjanjian pada rumah-rumah sakit kelas B dengan fasilitas kedokteran Madya telah menyuburkan tindakan medis 
yang un-medically needed (tindakan kedokteran yang tidak diperlukan). Merupakan kebalikan dari Up Coding; Up coding adalah tindakan penyesuaian yang dilakukan operator di Rumah Sakit khusus yang mengurus claim pembayaran BPJS terhadap rumah sakit atas dasar INA-CBGs, namun juga membuat penyesuaian agar sesuai dengan standar pembayaran BPJS. Sebagai ilustrasi adalah bila BPJS (INA-CBGs) hanya membayar Rp. 250.000 untuk $2 \mathrm{~cm}$ robekan di kulit dan daging maka operator harus melakukan penyesuaian terhadap satu robekan yang hanya $1,5 \mathrm{~cm}$ menjadi $2 \mathrm{~cm}$. Jika tidak demikian maka tidak dibayarkan oleh BPJS.

Peraturan yang telah dikeluarkan oleh jajaran Kementerian Kesehatan untuk mencegah tindakan kedokteran yang tidak diperlukan secara khusus yaitu adanya scheme Up-Coding. Semuanya tergantung pada situasi bahwa seorang tenaga spesialis berhadapan dengan tantangan untuk menjaga medical staff privilege yang dimilikinya di rumah sakit, dan tuntutan target yang harus dipenuhi, sebagai akibat dari adanya teknologi kedokteran yang diperlukan di bidang spesialisasinya. Beberapa Rumah Sakit Swasta dengan standar Madia (B) mengaitkan teknologi kedokteran yang digunakan oleh rumah sakit, dihubungkan dengan bidang perawatan spesialis yang ditawarkan oleh rumah sakit secara ekonomi membebani seorang dokter untuk mengejar target pemasukan keuangan demi teknologi dan peralatan kedokteran yang digunakan. Sebagaimana hasil wawancara peneliti pada seorang dokter spesialis yang nama pribadi maupun institusi rumah sakit tempatnya bekerja, tidak ingin dicantumkan.

Dalam implementasi Jaminan Kesehatan Nasional (JKN) telah diatur pola pembayaran untuk fasilitas kesehatan tingkat lanjutan adalah dengan INA-CBGs sesuai Peraturan Presiden Nomor 12 Tahun 2013 tentang Jaminan Kesehatan sebagaimana telah diubah dengan Peraturan Presiden Nomor 111 Tahun 2013. Untuk tarif yang berlaku pada 1 Januari 2014, telah dilakukan penyesuaian dari tarif INA-CBG Jamkesmas dan telah ditetapkan dalam Peraturan Menteri Kesehatan Nomor 69 Tahun 2013 tentang Standar Tarif Pelayanan Kesehatan Pada Fasilitas Kesehatan Tingkat Pertama dan Fasilitas Kesehatan Tingkat Lanjutan Dalam Penyelenggaraan Jaminan Kesehatan.

Semua tindakan staf medis yang melibatkan pertimbangan bukan medik untuk melakukan rujukan pasien (medically unnecessary), ataupun melakukan scheme up-coding ataupun target model. Semua itu berada di bawah radar utility review, apakah penggunaan tindakan tertentu diperlukan. Tim kajian penggunaan teknologi kedokteran di rumah sakit berada di bawah tanggung-jawab komite medik maupun direktur medik. Pelanggaran-pelanggaran terhadap protokol medis; seperti standar perawatan, standar pelayanan, professional misconduct selain berhadapan dengan ketentuan hukum, juga bertentangan dengan internal protokol di lingkungan profesi medik maupun rumah sakit. Terdapat dua dokumen yang mempunyai kekuatan hukum khusus, yaitu Hospital bylaws, hukum internal rumah sakit dan medical bylaws, ketentuan yang mempunyai kekuatan mengikat bagi staf medis sebagai medical staf previleges

\section{Kesimpulan}


Rumah Sakit dapat di mintakan tanggung gugat berdasarkan doktrin corporate responsibility dan vicarious liability, sebagaimana ketentuan Pasal 46 UU Rumah Sakit Nomor 44 Tahun 2009. Staf medis memiliki kewenangan klinis yang bersifat otonomi dan mandiri dalam menjalankan praktik di rumah sakit (medical staff previleges), sehingga secara individu berlaku tanggung gugat staf medis berdasarkan tanggung jawab profesi. Uraian tadi membuka lebar interpretasi hukum oleh hakim dalam memberikan petunjuk apabila timbul masalah, siapa yang harus bertanggung gugat, rumah sakit dan atau staf medis.

Secara khusus mengenai quasi economic credentialing dalam konteks Indonesia berlaku sistem target. Economic credentialing bisa saja belum secara terang-terangan dilaksanakan pada rumah sakit swasta di Indonesia, namun keberadaan "target model" yaitu kewajiban untuk menghasilkan jumlah tertentu dalam waktu tertentu merupakan fakta yang masih dapat diterima, meskipun efek dari kebijakan di atas dapat memunculkan implikasi-implikasi hukum tertentu pada sistem rujukan, penagihan pembayaran terhadap BPJS. Pertimbangan aspek ekonomi menjadi tanggung jawab hukum korporasi rumah sakit dan bukan menjadi bagian dari tanggung jawab profesi staf medis.

Kelalaian medis dalam persepsi hukum kesehatan berbeda dengan kelalaian umum menurut persepsi hukum. Dalam persepsi medis, ukuran suatu kelalaian terletak pada proses tindakan bukan pada hasil akhir. Untuk menilai terhadap proses tindakan tersebut, yang menjadi tolok ukur berbagai standar profesi dan pelayanan di lingkungan profesi kedokteran. Kompetensi untuk menilai dan mengevaluasi kelalaian itu pada komite medik yang merupakan perangkat rumah sakit yang melaksanakan fungsi kontrol profesionalisme staf medis di rumah sakit.

Kelalaian umum menurut perspektif hukum adalah perbuatan yang menyebabkan adanya korban , luka berat, cacat atau mati. Persepsi hukum melihat pada hubungan kausalitas antara sebab dan akibat bukan pada proses tindakan.

Sebagai rekomendasi teori pertanggungjawaban profesi kedokteran, selayaknya dikembangkan dan diarahkan pada perbuatan melawan hukum (Tort). Wilayah perbuatan melawan hukum pada lingkungan hukum perdata, sehingga memungkinkan industri kesehatan berkembang bersama-sama dengan industri asuransi kesehatan, farmasi maupun rumah sakit. Semua hal yang berhubungan dengan pelayanan kesehatan masuk dalam hukum privat dan bukan hukum publik. Let the original of law stays in adalah lebih baik keaslian dari sebuah tradisi tetap berlaku untuk menjamin adanya sebuah keadilan.

\section{Daftar Pustaka}

\section{Buku}

Tambun, J. G. (2016). Hukum Kesehatan Kedokteran dan Rumah Sakit. Manado: Pacific Institute for Sustainable Development Indonesia.

Koeswadji, H. H. (2002). Hukum Untuk Perumahsakitan. Bandung: Citra Aditya Bakti. 


\section{Jurnal}

Doerr, H. L. (1992). Economic credentialing. Quality Assurance and Utilization Review, 7(3), 91-94. https://doi.org/10.1177/0885713X9200700307

Blum, J. D. (1990). Hospital-Medical Staff Relations in the Face of Shifting Institutional Business Strategies: A Legal Analysis. U. Puget Sound L. Rev., 14, 561.

Black, S. B., \& Evans, R. W. (2012). Economic credentialing of physicians by insurance companies and headache medicine. Headache: The Journal of Head and Face Pain, 52(6), 1037-1040. https:/ / doi.org/10.1111/j.1526-4610.2012.02182.x

Cohen,B. (2004). An Examination of the Rigth of Hospitals to Engage in Economic Credentialing. Temp. L.Rev., 77, 705.

DiFranco, S. (2000). Denying medical staff privileges based on economic credentials. JL $\mathcal{E}$ Health, 15, 247.

Iheukwumere, E. O. (2000). Application of the Corporate Negligence Doctrine to Managed Care Organizations: Sound Public Policy or Judicial Overkill. J. Contemp. Health L. E Pol'y, 17, 585.

Enders, R. J. (1985). Federal Antitrust Issues Involved in the Denial of Medical Staff Privileges. Loy. U. Chi. LJ, 17, 331.

Riley, D. W. (1996). Economic credentialing of physicians: new criteria and evaluation of physicians. Spine, 21(1), 141-146.

\section{Seminar Pertemuan Ilmiah}

Nasser Mohammad. Pidana Medik Bukan Pidana Umum, Pertemuan Imiah Tahunan (PIT) Masyarakat Hukum Kesehatan Indonesia (MHKI), Jakarta, September 2017.

Tambun, J. G. (2015). Persoalan Private Order Versus Public Order Dalam Hubungan Dokter - Pasien, World Medical Congress, Denpasar Nusa Dua, Agustus 2015.

\section{Website}

American Medical Association. Staff Privileges. https://www.amaassn.org/delivering-care/staff-privileges, diakses 4 Juli 2019.

Brad Ranks. (2015). What Credentialing and Why is it Important. MEMD Blog https://blog.memd.me/what-is-credentialing-and-why-is-it-important/, diakses 4 Juli 2019.

Crowter Law Firm. Charitable Immunity for Nonprofit Hospitals. https://www.clflaw.com/Medical-Malpractice-Newsroom/Charitable-Immunity-forNonprofit-Hospitals.shtml, diakses 5 Juli 2019.

\section{Peraturan Perundangan-undangan}

Undang-Undang Nomor 29 Tahun 2004 tentang Praktik Kedokteran.

Undang-Undang Nomor 40 Tahun 2004 tentang Penyelenggaraan Jaminan Kesehatan dan Sosial Indonesia.

Undang-Undang Nomor 36 Tahun 2009 tentang Kesehatan.

Undang-Undang Nomor 44 tahun 2009 tentang Rumah Sakit.

Undang-Undang Nomor 36 Tahun 2014 tentang Tenaga Kesehatan.

Peraturan Presiden Nomor 111 Tahun 2013 tentang Jaminan Kesehatan.

Peraturan Menteri Kesehatan Nomor 755/Menkes/per/IV/2011 tentang Penyelenggaraan Komite Medik di Rumah Sakit.

Putusan Mahkamah Agung RI. No. 365 K./PID/2012, dr. Ayu Sasiary Prawani. dkk 
P-ISSN: 2302-528X, E-ISSN: 2502-3101

Putusan Mahkamah Agung RI. No. 79/PK/10/2013 tahun 2013, Dr Ayu Sasiary Prawany. dkk.

Pensylvania Supreme Court, 591 A.2d 70320 May 1991 Thompson v. Nason Hospital. 